\title{
Rapping the Shoah: (Counter-)Narratives and Judaism in German Hip-Hop
}

\section{THOMAS SEBASTIAN KÖHN}

\begin{abstract}
The Berlin-based rapper Ben Salomo has been disseminating hip-hop tracks that engage with collective memories and family memories of the Holocaust and World War II since 2016. He has also published an autobiography that addresses the subject. These memories are interwoven with various historical, political, and religious discourses with references to the ancient world, Jewish liturgy, and contemporary processes of othering. Focusing on the track "Identität," which was released in 2016, this article examines how memory narratives are negotiated differently in the track, in the autobiography, and in an interview conducted in 2019. Using a combination of music analysis, narrative analysis, and ethnography, the author elaborates how the track, in comparison to the autobiography and the interview, enables the negotiation of memory-related counter-narratives that not only abandon a victim-centered view but also question and criticize aspects of contemporary institutionalized memory culture. The inquiry shows how hip-hop serves as a medium for combining different musical elements and bringing a future-oriented yet reflective post-Holocaust perspective into a musical memory practice.
\end{abstract}

\section{Introduction}

The Berlin-based rap artist Ben Salomo combines discursive negotiations of "being Jewish" with statements against racism, discrimination, and right-wing populism in his songs. In this process, he draws on memories connected to National Socialism and the Holocaust and interweaves them with other historiographic and political representations. The track "Identität" (Identity), ${ }^{1}$ which was released on his 2016 album Es gibt nur einen (There is only one), makes this particularly clear. Salomo uses aspects of Jewish history and liturgy and connects them to autobiographical, family, and wider collective memories. The track was uploaded to YouTube with an accompanying music video and currently has about 193,000 views. ${ }^{2}$ In this article, I will use Salomo's work as a focus for broader musical considerations to investigate how negotiations and interweavings of memory, history, and politics are built upon the relationship of narratives and counter-narratives.

I will begin with a brief historical overview of research on hip-hop that addresses aspects of Judaism, being or identifying as Jewish, and intersectional marginalization. In the second part, I will describe my approach to the topic of narratives and counter-narratives on a theoretical and methodological level. I will then dedicate the third part to briefly exemplifying usages of different narrative formations in Jewish history. Since Salomo predominantly draws on narratives from the post-Holocaust period, I focus on elaborating narratives from this same context. Finally, I will analyze narratives and counter-narratives in different sources and elaborate on them as manifestations of narratives that existed beforehand, but are now embedded and discursively re-negotiated in the musical framework of a hip-hop track.

\footnotetext{
${ }^{1}$ All translations by the author unless otherwise stated.

${ }^{2}$ Accessed on February 24, 2021. 


\section{Hip-Hop, Judaism, and memory culture}

Up until now, studies investigating Jewish hip-hop in relation to memory culture have focused on Israeli and Palestinian hip-hop, ${ }^{3}$ and on artists from the US. In her study on hip-hop in South Tel Aviv, Miranda Crowdus analyzes the relationship between Jewish and non-Jewish artists, audiences, and identities. Drawing on Halbwachs's understanding of local collective memories and on Yael Zerubavel's ideological collective memory, she demonstrates how historical events are reshaped in collective discourses to "construct a national future" ${ }^{4}$ and to understand how communities inside and outside hip-hop interrelate. ${ }^{5}$ The representation of Israel as a hegemonic power and the role of Palestinian activism in hiphop have been discussed by David McDonald. ${ }^{6}$ In his study "Junction 48," he critically analyzes the music video "If I could Go Back in Time" and the film Junction 48 by the politically engaged Palestinian rap group DAM and shows how topics of gender, vulnerability, and Palestinian activism against Israeli hegemony coincide. ${ }^{7}$ Of particular interest here are the studies by Jon Stratton. ${ }^{8} \mathrm{He}$ understands what he calls "Jewish sampling" as a Holocaust- and memory-related cultural practice, based on montage, or on a recombination of fragments, as he calls it: "The idea of a rupture, often understood as catastrophe, and a combining of fragments, also saturates the ways the destruction of Ashkenazi culture in the Holocaust and the postHolocaust (re)constitution of a Jewish culture are talked about." Similarly, Jarula Wegner combines readings of Michael Rothberg's multidirectional memory and Foucault's counter-memory, ${ }^{10}$ applying them to the Jewish-American artists Remedy and Masta Killa, and to SoCalled, a Canadian artist of Jewish descent. Wegner states that the relation of their music to the marginalization of Jews in history and in the present, as well as activist articulations against marginalization based on memories of WWII, is only one side of the coin. The other side is about challenging and mobilizing their audience against marginalization in general. These topics are addressed in detail in the study European Others: Queering Ethnicity in Postnational Europe by Fatima El-Tayeb, which deals with discourses of racialization within Europe and analyzes feminist, queer and migrant performances-among others, in the context of hip-hop. ${ }^{11}$ In this process, her approach to queer and diasporic memory discourses is not teleological, but instead views them as fractured and fragmentary.

\footnotetext{
${ }^{3}$ Miranda Crowdus, Hip Hop in Urban Borderlands: Music-Making, Identity, and Intercultural Dynamics on the Margins of the Jewish State (Bern: Peter Lang, 2019), https://doi.org/10.3726/b14809; David A. McDonald, "Imaginaries of Exile and Emergence in Israeli Jewish and Palestinian Hip Hop," TDR 57, no. 3 (2013): 69-87, https://doi.org/10.1162/DRAM_a 00280.

${ }^{4}$ Crowdus, Hip Hop, 117.

${ }^{5}$ Ibid., 116.

${ }^{6}$ McDonald, "Imaginaries."

${ }^{7}$ David A. McDonald, “Junction 48: Hip-Hop Activism, Gendered Violence, and Vulnerability in Palestine,” Journal of Popular Music Studies 32, no. 1 (2020), 26-43, https://doi.org/10.1525/jpms.2020.32.1.26.

${ }^{8}$ Jon Stratton, "Sampling and Jewishness: A Short History of Jewish Sampling and its Relationship with Hip-Hop," Shofar 34, no. 3 (2016), 50-75, https://doi.org/10.1353/sho.2016.0014.

${ }^{9}$ Ibid., 55.

${ }^{10}$ Jarula Wegner, "Kompetitiv-Multidirektionale Erinnerung im Medium der Rap-Musik," in Musik als Medium der Erinnerung. Gedächtnis - Geschichte, -Gegenwart, ed. Lena Nieper und Julian Schmitz (Bielefeld: Transcript, 2016), 191204, https://doi.org/10.14361/9783839432792-013.

${ }^{11}$ Fatima El-Tayeb, European Others: Queering Ethnicity in Postnational Europe (Minneapolis: University of Minnesota Press, 2011), https://doi.org/10.5749/minnesota/9780816670154.001.0001.
} 
There has, however, been no research to date on the subject of German hip-hop and Judaism. From a variety of perspectives, such as music analysis, ${ }^{12}$ diaspora, ${ }^{13}$ and political activism and resistance, ${ }^{14}$ there are numerous studies and approaches from diverse fields of hip-hop studies that are potentially fruitful for the topic of German hip-hop, including aspects of Judaism. With this article I aim, firstly, to open up hip-hop studies thematically to include German hip-hop movements that address topics connected to Judaism in general. Secondly, I aim to engage with a theoretical and methodological intersection between JewishGerman topics within the context of hip-hop studies and cultural memory studies and-conversely-to make a contribution to how cultural memory studies can profit from musicology.

\section{Theorizing and Methodizing (Counter-) Narratives}

Three media form the basis of this particular investigation: the hip-hop track "Identität" by Ben Salomo; his autobiography, which was published in 2019; and a semi-structured interview I conducted with him in 2019. In these media, questions of narrative representation, especially those of individuals, topics and histories, are central. I will address these through the lens of narratives and counter-narratives. In a comparative analysis of autobiographies of German gangster rappers, Martin Seeliger references Stuart Hall, who describes an identity as something "always based upon a narrative, a kind of representation" 15 (emphasis mine). For this article, the understanding of narrative is of particular relevance. Seeliger points out that these are self-representations that refer to "different social affiliations as central points of reference." ${ }^{16}$ In order to make the concept of narrative productive for this work, I build on guiding questions posed by the historian Ute Daniel in her Kompendium Kulturgeschichte. ${ }^{17}$ Daniel's approach is primarily designed for the study of narratives in academic historiography but can nevertheless be profitably applied to the analysis of narratives within the context of my subject matter here. Drawing on Daniel, I will take into account the

\footnotetext{
${ }^{12}$ Oliver Kautny, "Ridin' the Beat. Annäherungen an das Phänomen Flow," in Die Stimme im HipHop: Untersuchungen eines intermedialen Phänomens, ed. Fernand Hörner and Oliver Kautny (Bielefeld: Transcript, 2009), 141-69, https://doi.org/10.14361/9783839409985-007; Tilo Hähnel, “Metrische und sprechnahe Zeitgestaltung des Rap im historischen Wandel," Samples 18 (2020), 1-21; and Michael Ahlers, “'Kollegah the Boss': A Case Study of Persona, Types of Capital, and Virtuosity in German Gangsta Rap," Popular Music 38, no. 3 (2019), 457-80. https://doi.org/10.1017/S0261143019000473.

${ }^{13}$ Ayla Güler Saied, Rap in Deutschland: Musik als Interaktionsmedium Zwischen Partykultur und urbanen Anerkennungskämpfen (Bielefeld: Transcript, 2012), https://doi.org/10.14361/transcript.9783839422519; Serhat Güney, Cem Pekman, and Bülent Kabas, "Diasporic Music in Transition: Turkish Immigrant Performers on the Stage of 'Multikulti' Berlin," Popular Music and Society 37, no. 2 (2012), 132-51, https://doi.org/10.1080/03007766.2012.736288; Martin Seeliger, “Autobiografien deutscher Gangsta-Rapper im Vergleich," in Deutscher Gangsta-Rap II: Popkultur als Kampf um Anerkennung und Integration, ed. Martin Seeliger and Marc Dietrich (Bielefeld: Transcript, 2017), 37-60, https://doi.org/10.14361/9783839437506; and Martin Seeliger and Marc Dietrich, "Zur Einleitung: Stigmatisierungsdiskurs, soziale Ungleichheit und Anerkennung oder: Gangsta-Rap-Analyse als Gesellschaftsanalyse," in Deutscher Gangsta-Rap II: Popkultur als Kampf um Anerkennung und Integration, ed. Martin Seeliger and Marc Dietrich (Bielefeld: Transcript, 2017), 7-36, https://doi.org/10.14361/9783839437506-001.

${ }^{14}$ Tricia Rose, Black Noise: Rap Music and Black Culture in Contemporary America (Middletown, CT: Wesleyan University Press, 1994); Marc Dietrich, "Samy Deluxe' Adriano (2018): Eine Analyse von Rassismus(kritik)konstruktionen aus Perspektive der Grounded-Theory-Methodologie" in Rap - Text - Analyse Deutschsprachiger Rap seit 2000: 20 Einzeltextanalysen, ed. Dagobert Höllein, Nils Lehnert, and Felix Woitkowski (Bielefeld: Transcript, 2020), 113-24, https://doi.org/10.14361/9783839446287-009; Matthew Oware, I Got Something to Say: Gender, Race, and Social Consciousness in Rap Music (Cham, Switzerland: Palgrave Macmillan, 2018), https://doi.org/10.1007/978-3-319-90454-2; and Christopher Vito, The Values of Independent Hip-Hop in the Post-Golden Era: Hip-Hop's Rebels (Cham, Switzerland: Palgrave Macmillan, 2019), https://doi.org/10.1007/978-3-030-02481-9.

${ }^{15}$ Martin Seeliger, "Autobiografien," 40.

${ }^{16}$ Ibid.

${ }^{17}$ Ute Daniel, Kompendium Kulturgeschichte: Theorien, Praxis, Schlüsselwörter, 6th ed. (Frankfurt: Suhrkamp, 2014).
} 
"historical-philosophical lines,"18 that is to say, the "grand narratives" of the respective sources under consideration. ${ }^{19}$ In a second step, I examine which representations of time are present: for example, do narratives of National Socialism (which figure prominently in Salomo's oeuvre) always portray the period as a single, or isolated historical event, or are other "times" also depicted and integrated into the narrative, e.g., earlier catastrophes or political patterns of thought? Furthermore, I investigate which individuals or collectives are privileged or marginalized by the narratives, for example, by particular emphases or omissions. In the course of this contextualization of power relations, it is also relevant to consider what is also left unsaid, ${ }^{20}$ what is "overlooked as insignificant and cut off from the collective narratives sustaining identity," 21 or what Astrid Erll calls the "other basic operation of memory: forgetting." 22 Possibly the most essential point is the analysis of how the narratives are in fact constructed, i.e., which stylistic devices, such as metaphors and comparisons, are employed..$^{23}$

One specific form of narrative is that of the counter-narrative. The prefix "counter" generally refers to the fact that these are narratives cut across established narratives that are the most prominent in collective memory or in so-called historical canons. They challenge and renegotiate discourses of power, knowledge, and truth. Drawing on Miranda Crowdus's research on Jewish rappers in South Tel Aviv, I will discuss counter-narratives in the context of collective "narratives of dispossession" 24 and "replacement ideologies." 25

Ann Rigney argues that "the lack of a pre-given connection between events and the way we later talk about them means that certain 'models of remembrance'... have evolved that are applied to multiple situations." ${ }^{26}$ For example, to make the opaque chaos of war understandable and tolerable, selected narratives and models of remembrance are employed. Rigney characterizes these models as a "changing repertoire of narrative structures. ${ }^{27}$ If we assume that, as Rigney puts it, collective narratives are produced in politically charged spaces regulating what is important and sayable, we can conclude that these repertoires may also depend on the kind of medium in which they are negotiated. A hip-hop track, for example, might be politically charged differently than an autobiography, resulting in different ways of addressing a similar topic (e.g., the Holocaust). For Rigney, ${ }^{28}$ this understanding of narratives can be compared to that of a monument, but one that is not limited in terms of its own localization. As a kind of "portable monument," narratives are thus generally politically charged and can be re-articulated (albeit transformed) in various other media. ${ }^{29}$

In order to illustrate how narratives and counter-narratives are constructed and employed in these media, I will first provide a historical overview of the various narratives connected to Judaism and the Holocaust. I will touch on several examples that show that the narratives presented here are not new, per se, but are instead re-negotiated in a broader context of hip-hop: the interview, the autobiography, and the track.

\footnotetext{
${ }^{18}$ Ibid., 440.

19 Ibid.

${ }^{20}$ Ibid., 441.

${ }^{21}$ Ann Rigney, "Remaking Memory and the Agency of the Aesthetic," Memory Studies 14, no. 1 (2021): 11, https://doi.org/10.1177/1750698020976456.

${ }^{22}$ Astrid Erll, “Travelling Memory,” Parallax 17, no. 4 (2011): 14, https://doi.org/10.1080/13534645.2011.605570.

${ }^{23}$ Daniel, Kompendium Kulturgeschichte, 440.

${ }^{24}$ Crowdus, Hip Hop, 119.

${ }^{25}$ Ibid., 71.

${ }^{26}$ Ann Rigney, "Cultural Memory Studies. Mediation, Narrative and the Aesthetic," in Routledge International Handbook of Memory Studies, ed. Anna Lisa Tota and Trever Hagen (New York: Routledge, 2016), 70.

${ }^{27}$ Ibid.

${ }^{28}$ Ann Rigney, "Portable Monuments: Literature, Cultural Memory, and the Case of Jeanie Deans," Poetics Today 25, no. 2 (2004), 361-96, https://doi.org/10.1215/03335372-25-2-361.

${ }^{29}$ Ibid.
} 


\section{Historicizing Narratives}

Different and sometimes seemingly contradictory narratives and perspectives are all a part of Jewish historiography. Some of these narratives existed in parallel and were taken up in a wide variety of media and discourses. At this point, this article does not claim to provide a holistic or chronological overview of narratives of Jewish history. Rather, it presents a selection of narratives that play a role in the media examined in this article. The narratives negotiated in the autobiography, the interview, and the hip-hop track display parallels to particular narratives of Jewish and Israeli history, especially concerning the post-Holocaust period. These consist of victim- and family-centered narratives of suffering on the one hand, and heroic narratives on the other. These types of narratives are contextualized historically in this section for further analysis.

Variations of victim- and family-centered narratives can be found in media representations in Israel, especially after the Eichmann trial. This 1961 trial, in which SS leader Adolf Eichmann was sentenced to be executed in Israel, received a great deal of media attention. In the wake of that event, victims of the Holocaust were also given a media platform for the first time. These "private stories of suffering" by families played a major role. ${ }^{30}$ As Daniel Levy and Natan Sznaider explain, "The stories that witnesses told during the trial were not about heroism and resistance, but survivors spoke about weakness, death, and vulnerability." 31 Levy and Sznaider refer to these as being increasingly talked about in families following the trial. The mediatization of the Eichmann trial can thus be seen as one of the first events to give family stories of suffering a representational space in the media and in family conversations.

The role of the television series Holocaust, which was first aired in 1978, should not be underestimated as an example of how this victim-centered narrative was outlined. In contrast to the Eichmann trial, the focus of discourse was no longer on the perpetrators, "but on the fictional story of a family of victims." 32 The series was widely discussed in both Germany and the US and was watched by about 100 million viewers in the US alone..$^{33}$ As early as 1987 , Robert Wuthnow analyzed viewer reactions to the series and noted viewers' attempts at orientation in the incomprehensible chaos and horror of the Holocaust. By combining fictional and non-fictional elements, the producer Marvin Chomsky translated the incomprehensible into a "language" that was more familiar to a larger part of the population. ${ }^{34}$ Part of that language comprised a range of narrative constructions the series drew on: "The Weiss family was conceptualized in such a way that virtually every American could effortlessly identify with it." ${ }^{35}$ With its mixture of the fictional and the non-fictional, the series formed a basis for narrative constructions that can be also found in films such as The Pianist and Schindler's List. Narrative aspects that have been criticized by many as a trivialization of the Holocaust, ${ }^{36}$ but which simultaneously make it possible to identify with the victims, play a core role here as well.

Salomo's work also reflects the influence of narratives discussed in this paragraph. These narratives, linked to an early collectivization of Judaism, can be found for example in the Jewish Orthodox journal

\footnotetext{
${ }^{30}$ Daniel Levy and Natan Sznaider, Erinnerungen im globalen Zeitalter: Der Holocaust (Frankfurt: Suhrkamp, 2007), 116, 128.

${ }^{31}$ Ibid., 128.

${ }^{32}$ Ibid., 137.

${ }^{33}$ Ibid.

${ }^{34}$ Robert Wuthnow, Meaning and Moral Order: Explorations in Cultural Analysis (Berkeley: University of California Press, 1987), 124-132.

${ }^{35}$ Levy and Sznaider, Erinnerungen, 138.

${ }^{36}$ Ibid.
} 
“Treue Zionswächter: Organ zur Wahrung der Interessen des Orthodoxen Judenthums" (Loyal guardians of Zion: Organization for the protection of the interests of orthodox Jewry). Here, a wide variety of historical constructions of "Judaism" was connected to a unified idea of a "people" and a "nation," as Philipp Lenhard points out in his work on Jewish historical narratives. Lenhard presents the narratives of that journal as an example of Orthodox Jews' resistance against modernization efforts in the mid-nineteenth century. Founded in 1845, the journal was a medium for aggregating traditionalists' arguments against the evolving changes toward a more open-minded Judaism. As a striking feature, Lenhard notes the authors' urge to construct Judaism as a unity consisting of a religion and an ethnicity: "Unmistakably, the ethnic definition of Judaism was mixed with the religious definition, in accordance with the pre-modern understanding of the rabbis." ${ }^{37}$ As he further states, "Judaism [as represented in the analyzed journal] should not only be recognized as an unchanging religion of revelation but also, faith and law, ancestry and cultus should not be separated from each other." ${ }^{38}$ As will be shown in the course of this article, this particular idea of Judaism consisting of a wide variety of elements affects Salomo's work as well. In the context of the establishment of the State of Israel, heroic narratives have continued to play an essential role in the post-Holocaust period. In their studies on the cosmopolitan memory of the Holocaust, Levy and Sznaider show that the narrative of passive victims had no place in the construction of a positive and "strong" image of the State of Israel. The authors state that "One, therefore, memorialized above all those victims who had resisted the Nazis." ${ }^{39}$ Thus, annihilation and heroism were negotiated simultaneously and institutionalized by the state, resulting in narratives of martyrdom.

However, these conflicting memories and narrative formations are not only related to historical aspects. The tension between victim and heroic narratives is renegotiated on various levels in sources connected to Ben Salomo. In the following sections, I will therefore outline different narrative formations in the interview, Salomo's autobiography, and the track "Identität." Starting with an analysis of victim narratives, I show that these types of narratives are predominant in my interview with Salomo and in his autobiography.

\section{"Some were deported to Auschwitz, others to Ravensbrück." Victim Narratives from Family Memory to Collective Memory}

In 2019, I interviewed Ben Salomo to better understand his perspective on negotiations of memory culture, which are of central relevance to some of his hip-hop tracks. In the interview, it turned out to be important for him to contextualize his relationship with his family, his family's relationship to the Holocaust, and its consequences for today's negotiations of Jewishness by non-Jewish people:

I would say that the history of the Jewish people is made up of family and individual histories of suffering. Or they simply share a story with each other. And they collectively share that history in their collective memory. Some were deported to Auschwitz, others to Sobibor, others to Treblinka, someone else to the Warsaw Ghetto, someone else to the Bershad Ghetto and so on

\footnotetext{
${ }^{37}$ Philipp Lenhard, Volk oder Religion? Die Entstehung moderner jüdischer Ethnizität in Frankreich und Deutschland 1782-1848 (Göttingen: Vandenhoeck \& Ruprecht, 2016), 203.

38 Ibid.

${ }^{39}$ Levy and Sznaider, Erinnerungen, 106.
} 
and so forth. These are different components that have one point in common: the Holocaust, as something that has entered the collective memory of the Jews as a whole. ${ }^{40}$

For Salomo, the high degree of interconnection between the Holocaust, Jewishness and family memory appears to be of major importance: in this context, a personal or more private conception of family is contrasted with a more collective constitution. Drawing on the understanding of narratives outlined in section 2 and 3, I will "unravel" these individual components and demonstrate how they are intertwined, as they form subcategories of the narrative of victimhood.

\section{Family narratives}

The family memory described by Ben Salomo is multifaceted and predominantly tied to addressing the suffering of both his own family — the private family_ and a more generalizing or meta-level concept of family ("the Jewish family"). The first category is that of the private family, similar to the "stories of suffering” mentioned above. ${ }^{41}$ While retelling his grandfather's memories from WWII, Salomo emphasizes the suffering and physical abuse during the Holocaust:

Then you find out, for example in Israel, where I was visiting my grandfather, he suddenly takes his teeth out of his mouth, and the front teeth were no longer there. Then he puts them on the table and I was like: Huh? . . . He tells me that a soldier, a German soldier knocked his teeth out of his face with the butt of a rifle when he was a young, very young man, almost a child. ${ }^{42}$

The teeth seem to extend the narrative layer of WWII memories by a further material layer. On the one hand, memories thus become "embodied" in a real sense. Both the teeth and the dentures can be regarded as objects of memory, as testimonies of suffering and abuse. Memories become inscribed into these objects. A shift regarding the carriers of memory ${ }^{43}$ is visible leading to a transmission across a divide: a table seems to separate Salomo and his grandfather. This spatial separation, however, is overcome by putting the dentures, these artifacts of abuse, right on the borderline between Salomo and his grandfather. The memories inscribed into this artifact are handed over to Salomo and hence to the next generation. The carriers of memory, and with them the victim narratives, are thus transferred, but they remain inside the frame of private family memories. Drawing on Daniel's understanding of narratives as elaborated in section two, a clear shift of the timeline can be seen. The memory narrative is characterized here by this handover from the grandparents' generation to that of the grandchildren. In contrast with Salmo's description of his grandfather as a victim of the Holocaust, in his biography, the grandfather is portrayed as a "real activist" 44 who was part of the "famous Israeli naval combat troops," seems to be a heroic narrative, but the further unfolding of this narrative in the biography shows a different side; the same paragraph describes how he founded a poultry farm that went bankrupt after a bird flu epidemic. $^{46}$

Other members of Salomo's family are described in the first part of the book Von Israel nach Deutschland-Meine familiären Wurzeln (From Israel to Germany-My family roots). Narratives of his

\footnotetext{
${ }^{40}$ Ben Salomo, personal communication, October 22, 2019.

${ }^{41}$ Levy and Sznaider, Erinnerungen, 128.

${ }^{42}$ Ben Salomo, personal communication, October 22, 2019.

${ }^{43}$ Erll, "Travelling Memory," 12.

${ }^{44}$ Ben Salomo, Ben Salomo bedeutet Sohn des Friedens (Munich: Europa Verlag, 2019), 24.

45 Ibid.

${ }^{46}$ See ibid.
} 
other grandfather, Alexander, as well as his twin brother, reflect contexts of escape, persecution, and hunger: "During the war, they were surrounded by the German Wehrmacht in Berschad and could no longer flee. ... Hunger spread further and further ... Alexander's twin brother also became sick at some point and died." ${ }^{\prime 7}$ Even when describing his family as a collective in a more general and abstract way, the victim roles remain: "My family experienced extermination, escape, persecution, emigration, ghettoization, hunger and misery by the Nazis and their allies." ${ }^{48}$ Drawing on Daniel's category of the group of persons represented by the narrative, a shift can be observed. The concept of family switches from a private collective, mentioned by their names, towards a broader understanding of family. The autobiography and the interview conceptualize "family" and family memory on a meta-level. This is not (only) about Ben Salomo's family, but also about a construction of "the Jewish family" as a collective. This meta-level becomes clear in the interview, where he talks about childhood memories:

There was something like a holocaust. You can't really understand it yet. You not only learn that people do not like you and that institutions have to be protected, but also that there was a huge murder, an unbelievable break in Jewish history, which every Jewish family had to suffer from. Including mine. ${ }^{49}$

The concept of the "Jewish family" is of particular interest and is addressed identically in different sections of the interview. Drawing on Crowdus's concept of "converging dispossessions," the construction of this meta-concept of family can be regarded as a converging or a collectivizing aspect. Memories of the Holocaust, then, form the basis of this meta-concept: the memories that the whole collective shares. On the one hand, the Holocaust as a history of suffering is inscribed into the concept of family. On the other hand, transformation processes become visible here, which cause family memories of suffering to transcend an understanding of family as "private" or even "biological." Understood as a collective family, it displays parallels to the representation of the collective construction of the Weiss family in the TV series Holocaust discussed in the section above. ${ }^{50}$ Erll refers to these abstractions of family memories as a "switchboard between the individual memory and larger frames of collective remembrance." individual to collective memory is, however, only one aspect in the above example. In particular, a collectivization of the victim narrative is prominent in the context of family memories. This has been a common factor in the construction of Jewish identity since long before the Holocaust. Aleida Assmann states: "With the Holocaust, all Jews were affected, therefore the posthumous are also part of this victim collective; in their memory they take the dead into their future." ${ }^{.52}$ Memories of the Holocaust reach into the present via collective construction, and—if one considers Assmann's point—even into the future.

\section{Post-memory narratives}

In the interview material, family memory is often negotiated as the "post-memory" of survival. Postmemory is a term coined by Marianne Hirsch, who uses it to describe the phenomenon of remembering events that are not immediately part of one's own experience, but which go back generations. In her research,

\footnotetext{
${ }^{47}$ Ibid., 18-19.

${ }^{48}$ Ibid., 22.

${ }^{49}$ Ben Salomo, personal communication, October 22, 2019.

${ }^{50}$ Levy and Sznaider, Erinnerungen, 137-138.

${ }^{51}$ Astrid Erll, "Locating Family in Cultural Memory Studies," Journal of Comparative Family Studies 42, no. 3 (2011), 315, https://doi.org/10.3138/jcfs.42.3.303.

${ }^{52}$ Aleida Assmann, Das neue Unbehagen an der Erinnerungskultur. Eine Intervention, 3rd ed. (Munich: C. H. Beck, 2020), 207, https://doi.org/10.17104/9783406652110.
} 
she discusses post-memory with reference to photographs, but the core concept can easily be applied to new contexts:

These photographs connect the two levels ... the past and the present, the story of the father and the story of the son, because these family photographs are documents both of memory (the survivor's) and of what I would like to call post-memory (that of the child of the survivor whose life is dominated by memories of what preceded his/her birth). ${ }^{53}$

The same principle of remembering another generation's events plays a significant role in the interview with Salomo, as he states: "I remember the Holocaust every day when I wake up. Because I am alive. That is, every morning when I get up, I know I am alive because someone in my family has survived, but his twin brother has not." 54 The statement "I am alive because someone else survived" signals the permeability between the life and the memories of Ben Salomo and his grandfather. The additional information "but his twin brother has not" also indicates the thin line between life and death, not only of his grandparents during the Holocaust, but also of his own life. If his grandfather had been murdered instead, Salomo would not be alive. This thin line between life and death seems to be one of the central aspects of this post-memory narrative. The narrative thus communicates not only what actually has been, but also what might have been (if his grandfather had been murdered). Using Daniel's idea of "historical representation," this narrative offers a double representational structure, reflecting both what actually happened and what theoretically could have been.

But is this not a narrative of survival rather than a narrative of victimhood? After all, this post-memory is connected to survival. On the one hand, the narrative emphasizes the grandfather's survival and Ben Salomo's life. On the other hand, the aspect of victimhood remains an undeniable factor in Salomo's negotiation of the past. Even though the aspect of "life through survival" plays a role, victimization in the context of the Holocaust is omnipresent, almost like a shadow. ${ }^{55}$ The momentum of survival is inextricably linked with the narrative of victimhood, since aspects of physical suffering during the Holocaust are present in those memories. The grandfather survived, but memories of suffering still dominate the memory discourse. The negative memories that Ben Salomo's grandfather shared with him live on in Salomo's memories and constitute a narrative basis for his own life. Being alive, in this case, turns out to be something special—as the exception in the context of murder and persecution.

\section{Narratives of Jewishness and othering}

The victim narrative goes hand in hand with a collective negotiation of Jewish othering:

I would say that as a Jew you carry this heavy, heavy backpack on your shoulders. ... And you realize how much strength you have to muster to carry this backpack. . . . They carry it because society around them sees them like this [as carrying a backpack]: Boah, you are a Jew, mmhm, what was that like? What happened to you guys? ${ }^{56}$

Through the rhetorical device of parody in the last sentence, Salomo illustrates his perspective on a construction of Jewishness that, from his point of view, is predominantly linked to collective memories of the Holocaust that lead to othering. The heavy backpack acts as a metaphor for the stigmatization Jewish

\footnotetext{
${ }^{53}$ Marianne Hirsch, “Maus, Mourning, and Post-Memory,” Discourse 15, no. 2 (1992-93): 8.

${ }^{54}$ Ben Salomo, personal communication, October 22, 2019.

${ }^{55}$ Interestingly, parallels can be drawn here to the discourse surrounding family and victimhood as discussed in the context of medial representations of victims during and after the Eichmann trial discussed in the section above.

${ }^{56}$ Ben Salomo, personal communication, October 22, 2019.
} 
people experience in the context of a predominantly "Western" discourse, charging the term "Jewish" with the role of "passive" Holocaust victims. The tool of parody is introduced by a sudden change of intonation in his voice and by using the word "Boah," a German vernacular expression for extreme surprise. The change of intonation indicates a change of perspective. It is not Salomo speaking, he is ironically mimicking someone. Salomo parodies the exoticizing effect of the statement, pointing out that it reduces Jewishness to victimhood and that it is an external attribution. Furthermore, the question "What happened to you?" shows the discursive naturalization of the passive victim narrative in collective memory. According to Daniel, it is important to read what is not being said: The parodic mirroring of the "western" perspective excludes the perpetrators. The question is not "Who did that to you?" or "What did the Nazis do to you?" Othering is constructed along the lines of victimhood and ascribed to Jewishness, but this construction hides any involvement of a guilty party.

In summary, the victim narrative combines post-memory with family memories and encapsulates different levels of abstraction of the concept of family. The memories are dominated by suffering during the Holocaust, which is further inscribed in the various concepts of family. But that suffering generally also implies survival, whereas othered constructions of Jewishness generally remain on the level of passive victimhood. The last narrative in this section also critically points to this construction of the connection between being Jewish and the Holocaust through the use of irony. It will therefore come as no surprise that Salomo seems to feel the need to constitute a narrative that challenges this very socially dominant narrative, as I will show in the analysis of his song "Identität."

\section{"Even Auschwitz could not kill my people": Counter-Narratives in the Hip-Hop Track "Identität"}

I have three names (Jonathan)

From three generations (Ben Salomo)

Passed on from father to son (Ben Aryeh)

Witnesses of identity, three names for three lives

I must uncover the meaning

...

What meanings will be revealed? ${ }^{57}$

The elaboration of the meanings of his stage names in their historical contexts form the central plot of the track. Jonathan is his given name, ${ }^{58}$ whereas Salomo and Aryeh are the names of his father and grandfather. "Ben" in front of each name indicates the male ancestor, in the sense of "son of." In the song's intro, his Hebrew stage name is rapped for the first time when he is called up to the Torah, highlighting an understanding of identity closely connected to Judaism. These meanings are also linked to memories of the Holocaust, which, together with other historical references, are shaped into different narratives.

To keep a clear structure and avoid redundancies, I will start with a schematic representation of the lyrics and only refer to the line numbers in the analysis. The lyrics of the chorus following each verse can be found at the beginning of this section.

\footnotetext{
${ }^{57}$ Ben Salomo, "Identität," in Es gibt nur einen (Berlin: Baba City, 2016), compact disk.

${ }^{58}$ I will use the spelling of the name "Jonathan" given in the CD liner notes.
} 


\begin{tabular}{|c|c|}
\hline & [Intro] \\
\hline 1 & At that time I was only thirteen \\
\hline 2 & As a little boy I felt as if I were standing at the foot of Mount Sinai \\
\hline 3 & But I was never a coward, I gathered up all my courage \\
\hline 4 & When a voice called my name: \\
\hline 5 & Jonathan Ben Salomo Ben Aryeh \\
\hline 6 & Read the lines written for you in the Torah \\
\hline 7 & The three names of your identity \\
\hline & [Verse 1] \\
\hline 8 & Jonathan means gift of God, skip the comments \\
\hline 9 & I am the member of the old Kaosloge they said was dead \\
\hline 10 & Still I rain down a hail of razor-sharp words \\
\hline 11 & But in my case deeds follow words \\
\hline 12 & As prophesied in the Book of Revelation \\
\hline 13 & A Jew from the street rhymes in German language decades after the Holocaust \\
\hline 14 & No matter how many people died \\
\hline 15 & When people have dreams, they can plant trees on scorched earth \\
\hline 16 & Dare to start anew, like pioneers \\
\hline 17 & Like Paul McCartney, I want to turn gold into platinum and rack up euros. \\
\hline 18 & Perhaps my God-given gift lies therein \\
\hline 19 & Now the question is: \\
\hline \multirow[t]{2}{*}{20} & What's hidden behind your names? \\
\hline & [Verse 2] \\
\hline 21 & Ben Solomon means son of peace \\
\hline 22 & I am immortal \\
\hline 23 & For humankind everything is possible, even flying to the moon \\
\hline 24 & You want to shoot goals like Messi? \\
\hline 25 & I want to cross the Alps like Hannibal on elephants and defeat Rome \\
\hline 26 & Let others deal drugs \\
\hline 27 & I'd rather tediously walk the straight path \\
\hline 28 & And do my thing without playing games \\
\hline 29 & For the principles of my high goals \\
\hline 30 & If you want to know your future, you need to know where your roots lie \\
\hline 31 & Music is my great passion, without it I would have fallen \\
\hline 32 & In times of crisis, I'd have fallen and lain on the ground \\
\hline 33 & She named me the son of peace, for that I remain her \\
\hline \multirow[t]{2}{*}{34} & Faithful servant, even if I do not earn a single euro \\
\hline & [Verse 3] \\
\hline 35 & Ben Aryeh means son of the lion, Judea's proud king \\
\hline 36 & In my veins flows the blood of fighters and commanders \\
\hline 37 & It survived expulsion, pogroms and famines \\
\hline 38 & Even Auschwitz could not kill my people, but \\
\hline
\end{tabular}




\begin{tabular}{|c|c|}
\hline 39 & Perhaps this offering was necessary, while in Germany \\
\hline 40 & Synagogues were burning, my grandfather was able to escape from Europe. \\
\hline 41 & He escaped the flames of the death ovens, if he had been \\
\hline 42 & One of the six million no one would hear my message today \\
\hline 43 & But I am here and the mission is fulfilled, what started \\
\hline 44 & Millennia ago will one day be realized through my son. \\
\hline 45 & When he honors the names of his forefathers, he will rise as the \\
\hline 46 & as the heir of the Lion of Judea upon the king's throne. \\
\hline & [Outro.] \\
\hline 47 & Today I am over thirty, and as a man it seems to me \\
\hline 48 & As if I were standing on the summit of Mount Sinai \\
\hline 49 & Yet before you stands no coward, I gather all my \\
\hline 50 & Courage when his voice calls my name: \\
\hline 51 & Jonathan Ben Solomon Ben Aryeh, Jonathan Ben Solomon Ben Aryeh \\
\hline 52 & Read the lines that are written for you in the Torah, the three names of your Identity \\
\hline 53 & My identity! \\
\hline
\end{tabular}

\section{Post-Holocaust narratives}

The first narrative I would like to address functions very similarly to what Crowdus, in discussing the introduction to a live concert by the Jewish rapper Subliminal, refers to as a "stereotypical story of the birth of the State of Israel, which is characterized by a threat to the Jewish collective that is overcome despite all odds." ${ }^{59}$ Subliminal addresses the Middle East conflict, making the thematic focus slightly different. However, the narrative of the Jewish collective overcoming threats remains a key similarity and shows parallels to narratives constructed in the context of the establishment of the state of Israel after the Holocaust. ${ }^{60}$ One of the most striking lines that demonstrates this narrative is line 13 . The statement "decades after the Holocaust" opens up a perspective on the Holocaust that still includes it as a central aspect of thought, but which opens up the possibility for thinking beyond it. In the same line, seeming opposites are combined: the combination "Jew" and "in German" allows a reading along the lines proposed by Daniel as a stylistic device, in this case for combining the perceived incommensurable. ${ }^{61}$ Accordingly, the postHolocaust narrative allows for renegotiations of aspects formerly understood as opposites, thus enabling a modern perspective of heterogeneity.

Central to this narrative is a rejection of victim perspectives. Salomo achieves this with a paradigm shift that moves away from suffering and persecution to a focus on survival, and thus on metaphors of a new beginning (lines 14-16). ${ }^{62}$ While the deaths of those who died are by no means "forgotten," the representation is much more centered on those who, as Stratton might put it, fragmentarily reassemble Jewish culture after the Holocaust. ${ }^{63}$ Meanwhile, the metaphors of scorched earth and planted trees, and the comparison of survivors with pioneers, are central to the post-Holocaust narrative. The Holocaust is still a

\footnotetext{
${ }^{59}$ Crowdus, Hip Hop, 125.

${ }^{60}$ Levy and Sznaider, Erinnerungen, 106.

${ }^{61}$ Daniel, Kompendium Kulturgeschichte, 441.

${ }^{62}$ Daniel, Kompendium Kulturgeschichte, 440.

${ }^{63}$ Stratton, "Sampling," 55.
} 
central issue, but the way it is dealt with is shifting towards a future-oriented perspective, while actively reflecting the past.

Another central aspect is the idea of the pluralization of (survived) holocausts, outlined (implicitly) in the third verse by the use of plural and generalized forms (line 37). Even though the likelihood is high that listeners will interpret these accounts as associated with the "one" Nazi Holocaust, it enables an interpretation of these aspects as belonging to many Holocausts throughout history via the employment of generalized forms of "persecution" and starvation, as well as by the plural form of "pogroms." The interview supports this interpretation: "The Holocaust is actually only the latest Holocaust, because there have been many Holocausts in Jewish history." ${ }^{64}$ In particular, the combination of the term "Auschwitz" in the lyrics with the word "even" distinguishes the Nazi Holocaust from further "pogroms, starvation and persecution."

The post-Holocaust narrative moreover offers the possibility of contrasting and destabilizing an institutionalized and canonized non-Jewish representation of Jewishness and Jewish history in which only one Holocaust exists. Intra-Jewish perspectives typically see the Holocaust as one of many instances in a long line of experiences of persecution involving slavery, forced assimilation, murder, and genocide. Salomo's opposing perspective on history, with its particular emphasis on this plurality of events of murder and persecution that actually happened, explicitly refers to pogroms, murders, and expulsions against Jews as repeatedly occurring throughout history.

\section{Jewish unity narrative}

The counter-narrative of Jewish unity as represented in the song makes use of two central units. Firstly, the concept of the private family and the Jewish family as a meta-concept repeatedly finds its way into the lyrics, constructing the idea of the Jewish collective. ${ }^{65}$ Crowdus uses the term "converging dispossessions' to describe the temporary unification brought about in the process of music-making by evoking collective memories and collective experiences of trauma." ${ }^{266}$ The principle here is very similar, except that the experiences of the Shoah take the place of dispossession. Secondly, Zionist perspectives find their way into this narrative. Crowdus describes the reaction to external threats as one central aspect to Zionist narratives: "The articulation of such threats in this environment is particularly useful in stimulating Jewish, group cohesion." ${ }^{\prime 7}$

Salomo refers to his natal family, specifically his grandfather, who was able to escape from Auschwitz (40-42). The narrative up to a point is relatively congruent with a victim narrative. At the same time, however, the grandfather in lines 41-42 is remembered precisely not as one of the six million Jewish victims of the Holocaust, but as a survivor. Thus, the grandfather represents a heroic narrative, as one of the survivors and moreover as one of those who managed to escape. Parallels can be drawn here to the collective remembrance of Jewish martyrs and resistance in the context of the founding of the state of Israel shortly after WWII. $^{68}$

Like in the victim narratives, the family concept in this counter-narrative is not limited to the private family. The concept of the "Jewish family" is not explicitly mentioned in this track. But the concept of "people" (line 38) appears to take on a very similar function; as lines 36-38 indicate, expressions such as "in

\footnotetext{
${ }^{64}$ Salomo, personal communication, October 22, 2019.

${ }^{65}$ See section 2.

${ }^{66}$ Crowdus, Hip Hop, 119.

${ }^{67}$ Ibid., 125.

${ }^{68}$ This has been outlined in section 3. See Levy and Sznaider, Erinnerungen, 106.
} 
my veins flows the blood of fighters and commanders," construct a collective similar to the family via the binding element of "Jewish blood," collective image with the aspect of ancestry can be linked to the approach of combining religion and ethnicity as stated in the context of the journal "Loyal guardians of Zion" from $1845 .{ }^{70}$ The image of ancestors serves as a basis for collective unification. The shared past of catastrophes enforces the construction of a collective and links it to attributes of strength and power.

\section{Empowering narratives}

Many of the lines can be read as empowering counter-narratives. The "pioneers daring to start anew and planting trees on scorched earth" (lines 15-16) may be understood as a call-out, as listeners are directly addressed and challenged in line 20: "What is hidden behind your names?", daring the audience to compare themselves and their ancestry to the great deeds of Salomo's forebears.

Line 25 refers to the army commander Hannibal Barca, who traveled from Spain and crossed the Alps with elephants to fight against the Roman Empire in the war between Rome and Carthage in 200 BCE. Hannibal's army only barely lost the war, which is viewed as a kind of near-victory against the Roman Empire. ${ }^{71}$ In the lyrics, Salomo follows the same goal: to defeat the Roman Empire, which can be interpreted as an attempt to stabilize the empowering narrative, a reference to success against seemingly impossible odds. Drawing on Daniel's thoughts, this image of Hannibal extends the time span of what is represented here. While the victim narratives presented above depict time spans going back to only WWII, this counternarrative extends this by reaching back to the ancient world.

The construction of the Jewish people in lines 36-38 is not limited to the narrative of Jewish unity. The image of the heroic Jewish people as opposed to a collective of victims makes it transparent that collective memory is in constant flux and that memory is actively produced and can accordingly be changed. The interview with Salomo and the analysis of his autobiography show that the stigmatization and reduction of Jews as victims of the Holocaust is regarded as a burden-a burden that (from Salomo's perspective) dominates the collective memory. Portraying the Jewish people as heroic provides not only a counternarrative to this victim narrative, but also an alternate version of collective memory. Drawing on Daniel, the marginalized history of the Jewish people is articulated through the lyrics and thus moves into the memory discourse.

In the course of the track, Salomo also takes on a kind of role model function, in which he abstains from drugs, follows "high goals" and presents himself as active (11,28-29). References such as line 24-25, "you want to score goals like Messi." illustrate the aim of encouraging the listener to think about their own goals and strengths, and to put them into practice. That a reflection on one's own history is part of this empowerment narrative is shown in line 30: "If you want to know your future, you need to know where your roots lie." This is not just about Salomo's own history, or that of his grandfather during the Holocaust. Rather, it is about a message that he wants to spread, as indicated in line 43. This message consists of precisely this awareness of history and the shaping of the future, in which lessons are to be learned from history. Memories of the Holocaust are thus meant to be central aspects of collective memory discourses, but at the same time have to be understood as reflective elements in the present and in considerations of the future.

\footnotetext{
${ }^{69}$ Crowdus, Hip Hop, 126.

${ }^{70}$ See section 3 and Lenhard, Volk oder Religion?, 203.

${ }^{71}$ Pedro Barceló, Hannibal (Munich: C. H. Beck, 1998).
} 
Interestingly, the time span represented here is extended once again. But instead of only expanding it back into the past, the future is included as a central aspect, bridging past, present and future.

\section{Connecting the counter-narratives}

It has become clear that sharp distinctions between individual counter-narratives presented above are not possible. Instead, the narratives overlap, depending on the reading and interpretative perspective. Some aspects, however, are shared among all the counter-narratives found in the lyrics. Two such aspects are the constant reference to religion and the "replacement ideology"72 which I will exemplify below.

Salomo bases the post-Holocaust narrative in line 12 on a prophecy in the Book of Revelation. Also, in the intro and outro of the track, he presents a divine inspiration in the context of a conversation with God as the basis for his reflection on the meaning of his names (lines 1-7, chorus). Since the exploration of these meanings constitutes the central feature of the lyrics, the entire negotiation of the track can be regarded in terms of this religious reference. This is particularly evident in a recurring linguistic and music-aesthetic manifestation of the voice of God; the simulation of the voice is manifested in the backing vocals by modulation effects, such as reverb and by a sonic-spatial positioning of the voice "further back" in the recording. Various other allusions to Judaism can be found in the track, not least his chosen stage names manifesting themselves in the different counter-narratives. Crowdus shows similar aspects in her study on rappers in Tel Aviv, where references to religion are made to emphasize political messages. ${ }^{73}$

Another aspect Crowdus identifies is "replacement ideology": "In fact, Hip Hop can be viewed not only as resisting oppressive hegemonies, but also as offering its own replacement ideologies that often can be dogmatic in their own right." "What is striking about the lyrics of "Identität" is that the victim narratives (in Daniel's sense of the term) that occur in the interview and autobiography are not featured in the track. I would argue that the counter-narratives outlined here are neither meant to provide an additional perspective to remembering victims, nor to destabilize them in the sense of resistance. Instead, the counter-narratives are meant to replace narratives of passive victimhood.

It is important to note that the construction of the narratives of victimhood that are opposed by the counter-narratives is not limited to "the (mass) media" or antisemitic, right-wing discourses. Elad Lapidot established the term "anti-antisemitic discourse" with reference to the practice of constructing the "Jewish figure" as a "friend." Lapidot exposes this figure as an ambiguous or even ambivalent one: "Anti-antiSemitism has become a cornerstone for ... ultimate redemption from all prejudice, violence and genocide; from all evil." 75 In its consequence, however, this figure of friendship "entails indifference to difference." Connecting this argument to Salomo's counter-narratives, these can be understood as actively opposing institutionalized and hegemonial anti-anti-Semitic discourses and thus as an attempt to reclaim the power of remembering victims of the Holocaust. The narratives of Jewish unification, empowerment, and postHolocaust narratives in the track are intended to serve as a replacement ideology by forming an alternative collective memory, challenging institutionalized figures of "Jewish friends" and anti-anti-Semitic discourses.

\footnotetext{
${ }^{72}$ Crowdus, Hip Hop, 71.

${ }^{73}$ Crowdus, Hip Hop, 159.

${ }^{74}$ Ibid., 71.

${ }^{75}$ Elad Lapidot, “Jewish Friends: Contemporary Figures of the Jew: Introduction,” Jewish Studies Quarterly 27, no. 2 (2020): 105, https://doi.org/10.1628/jsq-2020-0008.

${ }^{76}$ Ibid.
} 


\section{Musical Manifestations of the Counter-Narratives}

Since the narratives are embedded in a musical context, I will now analyze how musical parameters contribute to the narrative constructions and thus to the memory discourse. For this purpose, I will first present the basic musical structure of the track and then identify how the rhyming and rhythm schemes of the rap support the narratives. Furthermore, I will analyze how other musical aspects, such as the arrangement and a set of musical motifs, contribute to the narratives.

The track has a constant tempo of about $90 \mathrm{bpm}$, and the basic instrumentation includes drums, bass and keyboard. The track opens with an intro and closes with an outro in which the musical arrangement is reduced: bass, drums and keyboard are not audible here, so that some of the frequently recurring melodic motifs - which I will analyze in more detail in the next section-are particularly prominent in these parts. Furthermore, the track consists of three verses and a chorus, which is repeated identically between the verses. The verses consist of a 12-bar form, whereas the chorus has 8 bars. ${ }^{77}$ Variations are created by differences in the overall playing intensity between verse and chorus and by omitting instruments (such as the keyboard) in the verse. Acoustic stops contribute to variations: Stops are variations in the track characterized by omitting certain instruments, groups of instruments, or even the arrangement as a whole, while the rap continues. These interruptions in the musical arrangement mean that the listener's attention is focused on the rap.

The track is characterized by live-sounding "physical" instruments, such as a drum-kit, bass guitar, keyboard, various string instruments and piano. The drum and bass sounds especially contribute to this impression, since - if they were not recorded live - they probably consist of live samples. The chord scheme is based upon a circular chord pattern, I-VI, in C minor. However, this progression is only slightly hinted at by keyboard sounds, since the bass consists of a rhythmic pedal tone on the root $\mathrm{C}$ with only rare variations, which keeps repeating continuously throughout the track.

I analyze the musical elements of the song as they relate to the rap and its narratives following Oliver Kautny's flow analysis. His method of analysis focuses on the relationship between the "metrics of voice and accompanying patterns." ${ }^{78}$ On the "horizontal axis ... different forms of rhythmic grouping"79 and "the role of tonally shaped, rhymed speech" ${ }^{\prime 0}$ form the concept of flow. These aspects of the flow contribute significantly to the counter-narratives. Rhythmic variation in the lines is, among other aspects, created by the sporadic rising of vocal pitches on individual syllables. According to the concept of flow, rhyme groupings of words form rap lines; this causes some words to fall on heavy beats and others on unstressed beats. It is noticeable that the words that emphasize aspects that are prevalent for the counter-narratives are often those placed on heavy beats; they are also pitched higher. As shown below with an example from the third verse, the flow emphasizes words such as "Auschwitz," "death ovens," and "survive" through melodic accentuation and rhythmic placement on the beat. Furthermore, the lines' rhymes are also layered on words that are central to the counter-narrative: Löwen (lions), König (king), Kommandeure (commanders), Hungersnöte (famines), mein Volk nicht töten (not kill my people). ${ }^{81}$ By emphasizing these words and

\footnotetext{
${ }^{77}$ A 12-bar form might remind some listeners of the blues form. However, none of the material analyzed here exhibits any further parallels to the blues.

${ }^{78}$ Kautny, "Ridin' the Beat," 147.

${ }^{79}$ Ibid., 148.

${ }^{80}$ Ibid.

${ }^{81}$ Only the aspects that are relevant for the study of counter-narratives are mentioned here. Since the flow and rhymes play an important role in the entire track, other, non-Holocaust related issues are emphasized by these musical parameters as well.
} 
phrases, the musical parameters of flow and rhyme contribute to the way memory discourses are negotiated in the track.

The voice itself displays little or no post-processing and is positioned centrally and relatively close to the listener in terms of the recording's panorama. In my opinion, emphasis was put on conveying an "authentic" image of the voice. This is done by enhancing particular details such as Salomo's breaths, possibly made more audible by compression during post-production. In the chorus, Ben Salomo's voice is doubled in a slightly lower pitch and positioned further to the left in the panorama. This gives the voice the character of backing vocals, which increases the lyrics' emphasis in the chorus.

But it is not only the musical element of the rap that contributes to the counter-narratives and thus negotiates a particular form of memory discourse. The stops, in which the musical arrangement pauses completely or partially for a short period of time, fall precisely on the phrases that are relevant to the counternarratives. These stops (the underlined lyrics) give specific parts of the lyrics a particularly prominent position and emphasize the readings of the counter-narratives presented above.

As prophesied in the Book of Revelation

A Jew from the street rhymes decades after the Holocaust in German language ...

Now the question is: What lies behind your name? ${ }^{82}$

Stops at these points foreground religious references as connecting the counter-narratives, as well as the post-Holocaust narrative and the empowering narrative. As a further example, stops in the third verse at the line "even Auschwitz could not kill my people" bring the unifying narrative to the fore. Many other examples in the verses enhance the counter-narratives in similar ways. Thus, musical parameters-in this case, the stops-contribute to the memory discourse.

Much of the scoring of the track is based on three recurring motifs. One regular motif is played by a picked string instrument, either a harp, a qānūn, or an oud. ${ }^{83}$ The two other characteristic motifs are played by a piano and strings. The harp motif is the most prominent, containing a $\mathrm{C}$ minor arpeggio with an added 9th, which stands out for its rhythm and sound aesthetics. Rhythmically, it is similar to the figure of a clave, ${ }^{84}$ one feature of which is the rhythmic accentuation of off-beats. The motif stands out especially in the intro, where the supporting musical framework of drums and bass is missing. The loosely rhythmical piano fills in the spaces between the harp motif in the form of a musical conversation. Another, yet less frequently occurring motif or sample consists of a string section that features several dissonances, quarter notes and glissandi. While the harp and piano motifs sound relatively consistent, the string motif is especially prominent in the chorus.

The aforementioned motifs represent the central musical characteristics and thus shape the specific way memory discourses — and among these counter- and victim narratives_-are negotiated in the track. The motifs' functionality can be described with what Susanne Binas-Preisendörfer refers to as "emotionally charged sound objects, ${ }^{\prime 5}$ but instead of specifically referring to historical facts, they evoke a sense of

\footnotetext{
${ }^{82}$ Salomo, "Identität."

${ }^{83}$ For the sake of simplicity, I will use the term "harp motif" in the following.

${ }^{84}$ A clave beat usually consists of a repeating rhythmic pattern comprising a mixture of dotted and undotted quarter notes (tresillo, often in a 3-2 or 2-3 ratio). This specific constellation of dotted and undotted notes creates characteristic rhythmic shifts involving accents on the off-beats.

${ }^{85}$ Susanne Binas-Preisendörfer, "Klangliche Repräsentationen des `Mauerfalls` in ausgewählten Hörfunkreportagen, Fernsehdokumentationen und fiktionalen Filmen," in Klang als Geschichtsmedium: Perspektiven für eine auditive Geschichtsschreibung, ed. Anna Langenbruch (Bielefeld: Transcript, 2018), 196, https://doi.org/10.14361/9783839444986$\underline{008 .}$
} 
historicity. Ben Salomo describes the motifs as being "just the way it sounded in the region at that time." 86 While it remains unclear what exactly he means by that, the statement suggests that the sense of historicity might play a bigger role here than "actual" sound-or music history. However, by contextualizing the music with topoi from the lyrics, like the counter-narratives, but also from other external points of reference, interesting parallels can be found. For example, if we compare Salomo's track to the movie The Pianist (2002), similarities can be found on various levels: firstly, both media discuss memories of the Holocaust from an intra-Jewish perspective including family memories of persecution, murder, and deportation. Related to this, both authors-Salomo as lyricist and Roman Polański as the film producer and directorshare family memories of the Holocaust, since several of Polański's relatives were also deported. Secondly, both media are intertwined with (auto)biographies. The track's connection to Salomo's autobiography is mentioned above and the film includes aspects of Polański’s own biography as well as Władysław Szpilman’s autobiography as a Jewish-Polish pianist. ${ }^{87}$ Most importantly, however, both media share music as a "transcending, universal language" 88 which will be discussed in more detail below.

If we compare Salomo's piano motif from the hip-hop track to the piano motif of the soundtrack of The Pianist, which features the Nocturne in C\# minor by Frédéric Chopin, similarities can be found regarding tonal resources, instrumentation, tempo, interval structures, rhythms, and micro-timing:

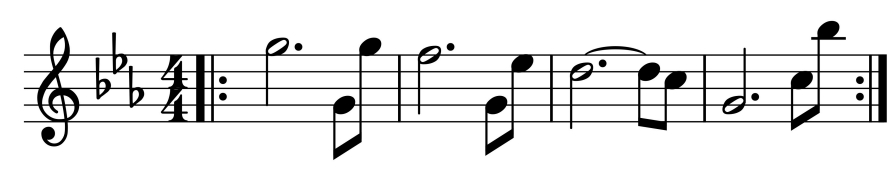

Figure 1: "Identität" measures 1-4. My transcription.

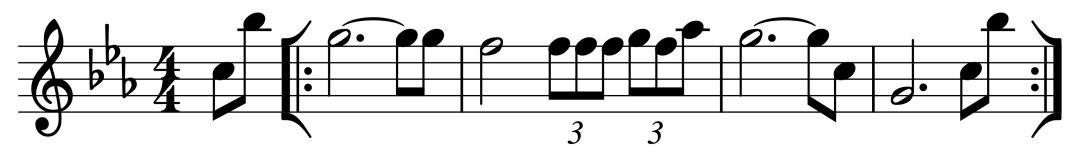

Figure 2: "Identität," recurring piano motif. My transcription.

\footnotetext{
${ }^{86}$ Ben Salomo, personal communication, October 22, 2019.

${ }^{87}$ Claudia Bullerjahn, "Der Soundtrack des Holocaust. Musik im Dienste einer Erinnerungskultur," in Sound des Jahrhunderts: Geräusche, Töne, Stimmen 1889 bis heute, ed. Gerhard Paul and Ralph Schock (Bonn: bpb, 2013$), 538$. ${ }^{88}$ Ibid.
} 

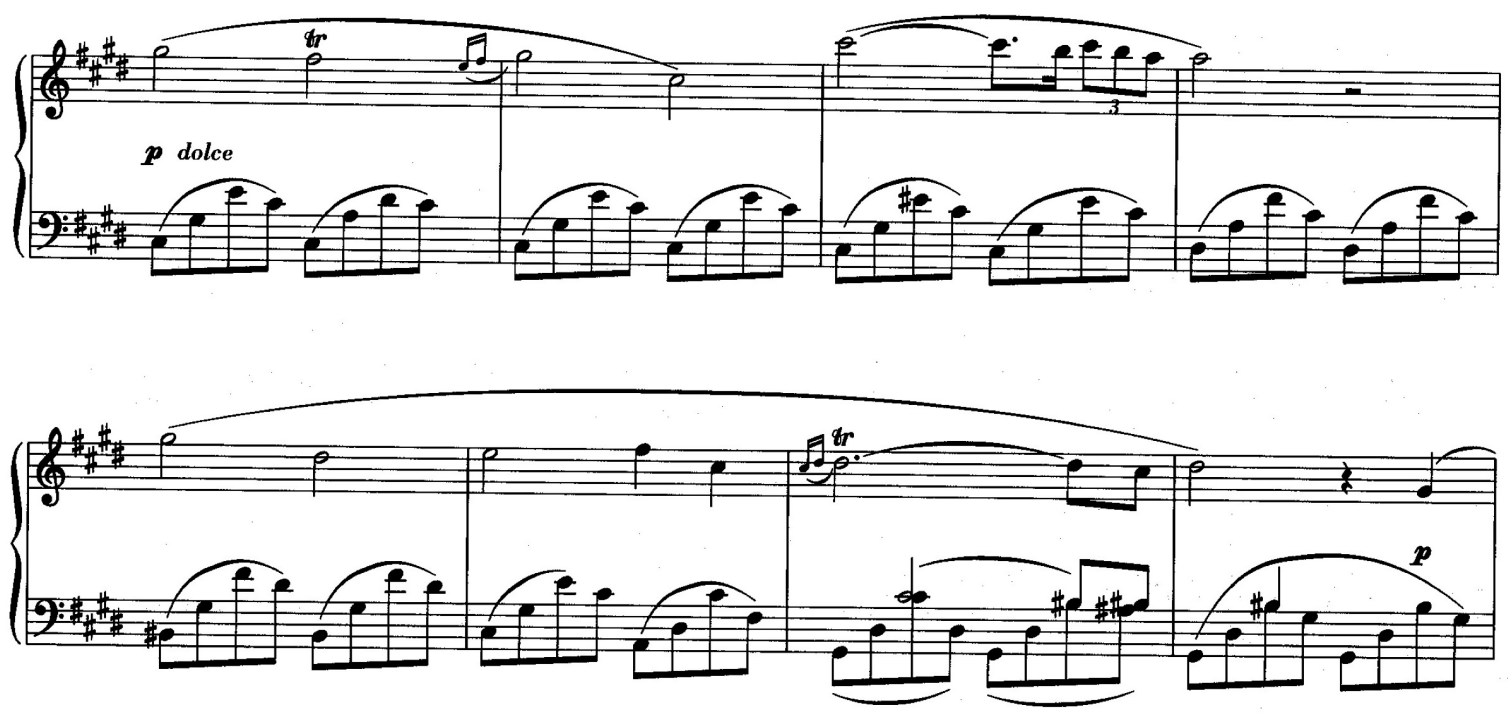

Figure 3: Frédéric Chopin, Nocturne C\# minor, measures 5-12.

If we compare the two themes, several aspects stand out: first, the melodic lines of the long half notes, or dotted half notes, are very congruent. While Figures 1 and 2 are in $\mathrm{C}$ minor and Figure 3 is in C\# minor, the long notes carrying the melody have the same functions in the harmonic context. In "Identität," the melody progresses from the fifth of the underlying $\mathrm{C}$ minor chord down via the fourth (or 11) and to the second (or 9). The Nocturne, which features in the soundtrack to the film The Pianist, shows a very similar progression. Comparing the long notes of the recurring piano sample from "Identität" with bars 5 and 6 from the Nocturne, it becomes clear that the melodic progression is almost identical. But as Claudia Bullerjahn points out regarding the film music of The Pianist, the music sounds "not specifically Jewish, but is rather a music that uses the Western conventions of conveying suffering." ${ }^{\prime \prime}$ Since various representations of suffering and sorrow have been accompanied by slowly and freely played piano passages in minor keys in different media, this motif from "Identität" may be associated with such narratives of grief in a similar way. Accordingly, the music does not only contribute to the negotiation of counter-narratives of the lyrics. Rather, the musical motifs seem to be able to provide intermedial parallels, for example to film and in this connection also to victim narratives, that play an important role in various media throughout (Jewish) history.

Following Bohlmann, the harp motif may be interpreted as an allusion to Jewish liturgical contexts: "In Genesis 4 we are to assume that the "harp" and "flute," "played" as they are by the generations that succeed Yuval, are musical instruments. . . there is an almost infinite variety of both harps and flutes ...."90 If interpreted in this way, there is a possibility that this motif supports the religious reference aspect as connecting the various counter-narratives and thus contributes to the memory discourse on a musical level. Since it is not entirely clear whether the motif is actually played by a harp, and not an oud or a qānūn, a connection to Mizrahi music (see below) may be relevant here as well.

\footnotetext{
${ }^{89}$ Bullerjahn, "Der Soundtrack des Holocaust," 540. In my work, I hold the position that there can be no such thing as a "specifically Jewish" sound and/or music.

${ }^{90}$ Philip V. Bohlmann, Jewish Music and Modernity (Oxford: Oxford University Press, 2008), xxii-iii.
} 
The second part of the string motif, which is played for the first time when Salomo raps his name in the intro (0:30), consists of the tones C, Db, Eb, F, G, Eb, F, D, and Eb. The tonal center of the piece is C minor and the track's basic scale is $\mathrm{C}$ aeolian. The pitch $\mathrm{Db}$ in this motif, however, signals more of a Phrygian scale, characterized by this particular semitone between the first and second tone $(\mathrm{C}$ and $\mathrm{Db})$. The very use of both the Aeolian and Phrygian scales in the track creates a tonal tension that makes this motif stand out. In addition, this $\mathrm{Db}$ from the motif is pitched slightly too low, creating a particular dissonance. Furthermore, the tonal steps from $\mathrm{F}$ to $\mathrm{G}, \mathrm{Eb}$ to $\mathrm{F}$, and $\mathrm{D}$ to $\mathrm{Eb}$ are played using glissandi, and the target notes are partially pitched slightly off-key. This creates a contrast to the rest of the track, which is intonated in perfect pitch. Regarding the tonal repertoire, parallels could be drawn to the "Jerusalem-Sephardi Style" 91 which has become a commonly used requisite in modern Israel for recitation circles since the twentieth or twenty-first century. ${ }^{92}$ Musically, there are similarities to the Arabic maqam as a significant tonal pool including tonal steps other than the "Western European" well-tempered tonal system. Specifically, the lower tetrachord of the Bayyātī ${ }^{93}$ shows parallels to the Phrygian mode and further includes the lowered second step from Salomo's motif.

But the constitution of this motif also allows for parallels to Mizrahi music. According to Crowdus, "Mizrahi music is a label used to describe all musical output of Jewish immigrants [to Israel] from the 'Arab' world," 94 and this music has a marginalized status in Israel compared to the dominant European culture. ${ }^{95}$ Since the 1960s, performers have combined this music with instruments and genres that are more commonly attributed to popular music. While the tonal pool of the accompanying arrangements is rather "Western," the singing has characteristic quarter-tone steps which, however, do not originate from traditional maqamat. ${ }^{96}$ The aspect of marginalization of the Mizrahi style and the similarities to the style allow for the possibility of reading this motif as a contribution to the empowering narrative or the unifying narrative. It could be connected to the above statement of converging dispossession on a musical level, as a collectivizing sound image. By specifically playing a motif potentially related to marginalized music, this can also be read as empowering against marginalization. Seen this way, sonic support of the empowering narrative and thus as a musical and sonic contribution to the memory discourse would then be a plausible way of reading the motif. Another possible way of hearing the string motif would be to see it as an entire musical unit, as the motifs are most frequently heard in the track. In this case, it would be possible to speak more abstractly of a sense of historicity, as Salomo's own statement would suggest. This musical historicity in connection with the historical dimension of the lyrics (specifically those parts referencing Jewish liturgy and history) may lead to an understanding of these motifs as a sonic support for shaping a (Jewish) collective and, hence, a collective memory.

\section{Conclusion and Consequences}

This article highlighted the roles of victim narratives in an interview with Ben Salomo and in his autobiography, as well counter-narratives in his hip-hop track "Identität." It showed that victim narratives

\footnotetext{
${ }^{91}$ Ibid., xxiv.

92 Ibid.

${ }^{93}$ Scott Marcus, "Modulation in Arab Music: Documenting Oral Concepts, Performance Rules and Strategies," Ethnomusicology 36, no. 2 (1992): 173, https://doi.org/10.2307/851913.

${ }^{94}$ Crowdus, Hip Hop, 49.

${ }^{95}$ Ibid.

${ }^{96}$ Ibid., 50.
} 
consist, on the one hand of two differently conceptualized notions of family: one embodies memories of escape and mistreatment of Salomo's (private) family (especially regarding his grandfather). The other conceptualizes family as a meta-category for negotiating "the Jewish family," that is, as a collective construction. On the other hand, there are clearly visible contours of post-memory, since Ben Salomo transmits the family's memories of expulsion and violence without having "actively" witnessed the Holocaust. The timeline of memories presented in the interview and the autobiography runs almost exclusively from the Nazi period to Ben Salomo's childhood and through to the present.

Central to the hip-hop track are counter-narratives that facilitate a post-Holocaust perspective, the idea of a unified (Jewish) collective and an empowering aspect for manifesting these narratives in collective memory. All counter-narratives share references to religion as a tool for political manifestation of the narratives. They moreover share a "replacement ideology," with an emphasis on the aim of replacing the victim narratives that are prominent in collective memory. In this regard, it is striking that the timeline presented in the track extends far beyond the Holocaust period, creating a bridge from ancient times to the future. This, in turn, is interwoven with aspects of empowerment, which are intended to encourage listeners to reflect on their own history. This replacement ideology further fosters and establishes a critical positioning against institutionalized memory discourses that enable the construction of victim narratives in the first place. Consequently, counter-narratives in the track are formed to criticize and destabilize hegemonic (memory) discourses that frame a specific "figure" of Jewishness closely connected to victimhood. ${ }^{97}$

When analyzing the music of the track, three motifs in particular stand out due to their instrumentation (harp, oud or qānūn, piano, and violin) as well as partly due to their melodic-tonal characteristics. Taking a closer look, parallels can be drawn between these motifs and Jewish liturgy and Mizrahi music (harp and string motif), film music (piano motif), and the tonal repertoire of maqamat (string motif). Those motifs can be read as bridging victim narratives and counter-narratives. While the piano motif can be read as linking to a broad range of victim narratives, such as from the movie The Pianist, the string motif can be linked to the marginalized role of Mizrahi music, due to its characteristic intonations. Furthermore, these motifs can be read as sound objects that are not directly charged with meanings of particular historical events, but rather associated with a broader meaning of perceived, or sensed historicity.

Since (especially) hip-hop is an art and cultural form in which the principle of montage is particularly central, it is worth taking a detailed look at the individual components that constitute a particular track. The tracks are not arranged, produced, or composed arbitrarily. Through their re-contextualization and interweaving with other elements, sonic components constantly take on new or changing connotations.

Thus, when researching memories in hip-hop, it makes sense, or may even be constitutive, to historicize these individual elements of the montage. And here, not only certain images, stylistic devices, or politics of the lyrics alone are to be mentioned, but also musical features, such as samples, modified and edited melodies, and motifs. In order to understand how a hip-hop track contributes to memory constructions, it is moreover of particular importance to listen closely to the particular flow of rap and the musical and sonic arrangement of the track. Hip-hop is also an art form that frequently highlights the individual rapper or ego and situates that person (often "him" rather than "her") in a heroic or in an antihero role. Accordingly, it would be fruitful for future research on hip-hop, memory culture, and Judaism to consider masculinity and gender in more detail.

${ }^{97}$ Lapidot, “Jewish Friends,” 105. 
Research on memory conceptualized in musicological thinking benefits-here I agree with Melanie Unseld $^{98}$ - from a consideration of material, mental, and social dimensions. In this context, we can think about the extent to which the consideration (perhaps in particular) of hip-hop as a medium of memory may increasingly offer a productive perspective for researching sounds in their memorability, and how sounds and music contribute to memory discourses. Identifying the concrete constitution of sound as memorable and arranged fragments— be it in the form of melodic motifs, lyrical narratives, samples, or rhythms-in music and making them describable is an important step. Since memories are historically specific, it is furthermore an important undertaking to historicize precisely those fragments in music that are associated with such diverse memories: They can be analyzed along with the discourses of memory in which they appear, processually change, and might even be lost again.

\section{Bibliography}

Ahlers, Michael. "'Kollegah the Boss': A Case Study of Persona, Types of Capital, and Virtuosity in German Gangsta Rap.” Popular Music 38, no. 3 (2019): 457-80.

https://doi.org/10.1017/S0261143019000473.

Assmann, Aleida. Das neue Unbehagen an der Erinnerungskultur: Eine Intervention. 3rd ed. Munich: C. H. Beck, 2020. https://doi.org/10.17104/9783406652110.

Barceló, Pedro. Hannibal. Munich: C. H. Beck, 1998.

Ben Salomo. Es gibt nur einen. Baba City Records, 2016.

Ben Salomo. Ben Salomo bedeutet Sohn des Friedens. Munich: Europaverlag, 2019.

Ben Salomo. Interview. October 22, 2019.

Binas-Preisendörfer, Susanne. "Klangliche Repräsentationen des 'Mauerfalls' in ausgewählten Hörfunkreportagen, Fernsehdokumentationen und fiktionalen Filmen.” In Klang als Geschichtsmedium. Perspektiven für eine auditive Geschichtsschreibung, edited by Anna Langenbruch, 183-218. Bielefeld: Transcript, 2018. https://doi.org/10.14361/9783839444986-008.

Bohlmann, Philip V. Jewish Music and Modernity. Oxford: Oxford University Press, 2008.

Bullerjahn, Claudia. "Der Soundtrack des Holocaust. Musik im Dienste einer Erinnerungskultur." In Sound des Jahrhunderts. Geräusche, Töne, Stimmen 1889 bis heute, edited by Gerhard Paul and Ralph Schock, 534-40. Bonn: bpb, 2013.

Chopin, Frédéric. Nocturne cis-moll: Opus postum. Munich: G. Henle, 2003.

Crowdus, Miranda. Hip Hop in Urban Borderlands: Music-Making, Identity, and Intercultural Dynamics on the Margins of the Jewish State. Bern: Peter Lang, 2019. https://doi.org/10.3726/b14809.

Daniel, Ute. Kompendium Kulturgeschichte: Theorien, Praxis, Schlüsselwörter. 6th ed. Frankfurt: Suhrkamp, 2014.

Dietrich, Marc. "'Samy Deluxe' Adriano (2018) Eine Analyse von Rassismus(kritik)konstruktionen aus Perspektive der Grounded-Theory-Methodologie." In Rap - Text-Analyse Deutschsprachiger Rap seit 2000: 20 Einzeltextanalysen, edited by Dagobert Höllein, Nils Lehnert, and Felix Woitkowski, 113-24. Bielefeld: Transcript, 2020. https://doi.org/10.14361/9783839446287-009.

\footnotetext{
${ }^{98}$ Melanie Unseld, "Musikwissenschaft und Erinnerungsforschung. Einige Vorüberlegungen,” in Musik als Medium der Erinnerung. Gedächtnis - Geschichte - Gegenwart, ed. Lena Nieper and Julian Schmitz (Bielefeld: Transcript, 2016), 29-38, https://doi.org/10.14361/9783839432792-002.
} 
El-Tayeb, Fatima. European Others: Queering Ethnicity in Postnational Europe. Minneapolis: University of Minnesota Press, 2011. https://doi.org/10.5749/minnesota/9780816670154.001.0001.

Erll, Astrid. "Locating Family in Cultural Memory Studies." Journal of Comparative Family Studies 42, no. 3 (2011): 303-18. https://doi.org/10.3138/jcfs.42.3.303.

Erll, Astrid. "Travelling Memory.” Parallax 17, no. 4 (2011): 4-18. https://doi.org/10.1080/13534645.2011.605570.

Forman, Murray, and Mark Anthony Neal, eds. That's the Joint: The Hip-Hop Studies Reader. New York: Routledge, 2004. https://doi.org/10.4324/9780203642191.

Güney, Serhat, Cem Pekman, and Bülent Kabas. "Diasporic Music in Transition: Turkish Immigrant Performers on the Stage of 'Multikulti' Berlin." Popular Music and Society37, no. 2 (2012): 132-51. https://doi.org/10.1080/03007766.2012.736288.

Güler Saied, Ayla, ed. Rap in Deutschland: Musik als Interaktionsmedium zwischen Partykultur und urbanen Anerkennungskämpfen. Bielefeld: Transcript, 2012. https://doi.org/10.14361/transcript.9783839422519.

Hähnel, Tilo. "Metrische und sprechnahe Zeitgestaltung des Rap im historischen Wandel." Samples 18 (2020): 1-21.

Hirsch, Marianne. “Maus, Mourning, and Post-Memory.” Discourse 15, no. 2 (1992-93): 3-29.

Kautny, Oliver. “'Ridin' the Beat. Annäherungen an das Phänomen Flow.” In Die Stimme im HipHop Untersuchungen eines intermedialen Phänomens, edited by Fernand Hörner and Oliver Kautny, 141-69. Bielefeld: Transcript, 2009. https://doi.org/10.14361/9783839409985-007.

Lapidot, Elad. "Jewish Friends: Contemporary Figures of the Jew: Introduction." Jewish Studies Quarterly 27, no. 2 (2020): 103-7. https://doi.org/10.1628/jsq-2020-0008.

Lenhard, Philipp. Volk oder Religion?: Die Entstehung moderner jüdischer Ethnizität in Frankreich und Deutschland 1782-1848. Göttingen: Vandenhoeck \& Ruprecht, 2016.

Levy, Daniel, and Natan Sznaider, Erinnerungen im globalen Zeitalter: Der Holocaust. Frankfurt: Suhrkamp, 2007.

Marcus, Scott. "Modulation in Arab Music: Documenting Oral Concepts, Performance Rules and Strategies.” Ethnomusicology36, no. 2 (1992): 171-91. https://doi.org/10.2307/851913.

McDonald, David A. "Imaginaries of Exile and Emergence in Israeli Jewish and Palestinian Hip Hop." TDR/The Drama Review 57, no. 3 (2013): 69-87. https://doi.org/10.1162/DRAM_a_00280.

McDonald, David A. “Junction 48: Hip-Hop Activism, Gendered Violence, and Vulnerability in Palestine," Journal of Popular Music Studies 32, no. 1 (2020): 26-43. https://doi.org/10.1525/jpms.2020.32.1.26.

Oware, Matthew. I Got Something to Say: Gender, Race, and Social Consciousness in Rap Music. Cham, Switzerland: Palgrave Macmillan, 2018. https://doi.org/10.1007/978-3-319-90454-2.

Polański, Roman, dir. The Pianist. Toronto: TVA Films, 2003.

Rigney, Ann. "Cultural Memory Studies: Mediation, Narrative and the Aesthetic." In Routledge International Handbook of Memory Studies, edited by Anna Lisa Tota and Trever Hagen, 65-76. New York: Routledge, 2016.

Rigney, Ann. "Portable Monuments: Literature, Cultural Memory, and the Case of Jeanie Deans." Poetics Today 25, no. 2 (2004): 361-96. https://doi.org/10.1215/03335372-25-2-361. 
Rigney, Ann. "Remaking Memory and the Agency of the Aesthetic." Memory Studies 14, no. 1 (2021): 10-23. https://doi.org/10.1177/1750698020976456.

Rose, Tricia. Black Noise: Rap Music and Black Culture in Contemporary America. Middletown, CT: Wesleyan University Press, 1994.

Seeliger, Martin. "Autobiografien deutscher Gangsta-Rapper im Vergleich." In Deutscher Gangsta-Rap II: Popkultur als Kampf um Anerkennung und Integration, edited by Martin Seeliger and Marc Dietrich, 37-60. Bielefeld: Transcript, 2017. https://doi.org/10.14361/9783839437506.

Seeliger, Martin, and Marc Dietrich. "Zur Einleitung: Stigmatisierungsdiskurs, soziale Ungleichheit und Anerkennung oder: Gangsta-Rap-Analyse als Gesellschaftsanalyse." In Deutscher Gangsta-Rap II: Popkultur als Kampf um Anerkennung und Integration, edited by Martin Seeliger and Marc Dietrich, 7-36. Bielefeld: Transcript, 2017. https://doi.org/10.14361/9783839437506-001.

Spielberg, Steven, dir. Schindler's List. Washington, DC: Universal Pictures, 1993.

Steinbrecher, Bernhard. Das Klanggeschehen in populärer Musik. Vienna: Böhlau, 2016. https://doi.org/10.7788/9783412506988.

Stratton, Jon. "Sampling and Jewishness: A Short History of Jewish Sampling and its Relationship with Hip-Hop.” Shofar 34, no. 3 (2016): 50-75. https://doi.org/10.1353/sho.2016.0014.

Unseld, Melanie. “Musikwissenschaft und Erinnerungsforschung. Einige Vorüberlegungen.” In Musik als Medium der Erinnerung. Gedächtnis - Geschichte, -Gegenwart, edited by Lena Nieper and Julian Schmitz, 29-38. Bielefeld: Transcript, 2016. https://doi.org/10.14361/9783839432792-002.

Vito, Christopher. The Values of Independent Hip-Hop in the Post-Golden Era: Hip-Hop's Rebels. Cham, Switzerland: Palgrave Macmillan, 2019. https://doi.org/10.1007/978-3-030-02481-9.

Wegner, Jarula. "Kompetitiv-Multidirektionale Erinnerung im Medium der Rap-Musik.” In Musik als Medium der Erinnerung: Gedächtnis - Geschichte, -Gegenwart, edited by Lena Nieper and Julian Schmitz, 191-204. Bielefeld: Transcript, 2016. https://doi.org/10.14361/9783839432792-013.

Williams, Justin A., ed., The Cambridge Companion to Hip-Hop. Cambridge: Cambridge University Press, 2015. https://doi.org/10.1017/CCO9781139775298.

Wuthnow, Robert. Meaning and Moral Order: Explorations in Cultural Analysis. Berkeley: University of California Press, 1987. 